\title{
MODEL MUSYAWARAH RENCANA AKSI PEREMPUAN (MUSRENA) RESPONSIF GENDER DI KOTA BANDA ACEH
}

\author{
Oberlin Silalahi \\ Fakultas Ilmu Sosial dan Ilmu Politik Universitas Proklamasi 45 \\ Yogyakarta \\ oberlin_up45@yahoo.com \\ Ratnawati \\ Fakultas Ilmu Sosial dan Ilmu Politik Universitas Gadjah Mada, \\ Departemen Politik dan Pemerintahan FISIPOL UGM Yogyakarta \\ ratnaugm@ugm.ac.id
}

\section{ABSTRAK}

Partisipasiperempuandalamperencaanaan pembangunan dan penganggaran dalam Musyawarah Perencanaan Pembangunan (Musrenbang) selama ini ternyata masih memiliki hambatan. Sebagai upaya penyelesaiannya, Pemerintah Kota Banda Aceh merumuskan strategi baru berupa Musyawarah Rencana Aksi Perempuan (Musrena) yang memberikan kesempatan partisipasi penuh pada perempuan sebagai upaya pengarusutamaan gender (PUG) dan Anggaran Responsif Gender (ARG) dari tingkat yang paling rendah yaitu desa/gampong. Penelitian ini bertujuan untuk mengelaborasi secara komprehensif tentang inovasi Musrena di Kota Banda Aceh. Melalui pendekatan kualitatif, data dalam 
penelitian ini didapatkan dari Focused Group Discussion (FGD), wawancara mendalam (Indepth-interview) dan desk-study (studi dokumen/dokumentasi). Hasil penelitian ini adalah: 1. Tumbuhnya motivasi dan kesadaran wanita di tingkat Gampong, kota/kabupaten untuk ikut berpartisipasi dalam perencaanaan pembangunan dan penganggaran yang responsif gender. 2. Musrena berbasis prinsip kesetaraan, anggaran yang berkeadilan gender, musyawarah dialogis, anti dominasi, keberpihakan kepada kelompok rentan, anti diskriminasi, dan pembangunan secara holistik.

Kata Kunci : Musrena, Pengarus-utamaan Gender, Anggaran Responsive Gender,

\section{ABSTRACT}

Based on the lack of women participation in development planning and budgeting within the Development Planning Meeting (Musrenbang), the government of Banda Aceh formulate a new strategy in the form of Council Action Plan for Women (Musrena) which provides an opportunity and full participation for women as gender mainstreaming (PUG) and the Gender Responsive Budgeting (ARG) on the lowest level; the village (gampong). This study aims to elaborate comprehensively on innovation of Musrena in Banda Aceh. Through a qualitative approach, the data in this study was obtained from Focused Group Discussion (FGD), interview (in depth-interview) and desk-study (documentation). The results of this study are: 1 . Growth of motivation and awareness level of women in the village, city /county to participate in development planning and gender responsive budgeting. 2. Musrena based on the principles of: equality, gender fairly budgets, dialogical negotiation, anti-dominant, partiality, antidiscrimination, and holistic principle.

Keywords : Musrena, Gender Mainstreaming, Gender Responsive Budget 


\section{A. Pendahuluan}

Sejak desentralisasi dilaksanakan di Indonesia pada tahun 1999, pemerintah pusat telah berupaya maksimal untuk memperluas dan memperbaiki partisipasi warga negara untuk terlibat dalam proses perencanaan pembangunan dalam forum yang disebut dengan Musyawarah Perencanaan Pembangunan (yang disingkat Musrenbang).

Sesuai dengan ketentuan dalam Undang-Undang No. 25 Tahun 2004, Musrenbang merupakan forum musyawarah tahunan yang dilaksanakan secara partisipatif oleh para pemangku kepentingan untuk menyepakati rencana kegiatan tahunan untuk tahun anggaran berikutnya, yang dilaksanakan mulai dari tingkat desa, kecamatan, kota/kabupaten, provinsi hingga nasional. Intinya, Musrenbang ini dapat dimaknai sebagai ruang dan kesempatan interaksi warga negara untuk merembukkan sesuatu secara partisipatif dan berakhir pada pengambilan kesepakatan atau pengambilan keputusan bersama. Di samping itu, Musrenbang ini juga bertujuan untuk menyepakati prioritas kebutuhan dan kegiatan beserta pemilahannya.

Walaupun demikian, selama ini dalam realitasnya banyak terjadi program, proyek, atau kegiatan pembangunan di daerah dan desa dilaksanakan dengan perencanaan yang tidak memperhatikan aspirasi masyarakat. Juga tanpa dilengkapi dengan data dan informasi wilayah, desa, atau kelompok sasaran secara lengkap dan akurat. Kajiannya masih dilakukan dalam waktu yang terbatas dan belum menggunakan model pendekatan yang dapat menyerap aspirasi dan kebutuhan masyarakat.

Di sisi lain, ketidak-setaraan pengambilan keputusan dalam hubungan horizontal juga nampak sering terjadi. Sebagai contoh, di beberapa masyarakat (termasuk dalam masyarakat Aceh), tradisi dalam memutuskan sesuatu perkara lebih didominasi kaum lakilaki dibandingkan dengan kaum perempuan. Akibatnya, wacana pemikiran, terutama dalam aspek kemasyarakatan, dinilai sering bias gender. Akibatnya banyak program, proyek ataupun kegiatan 
pembangunan, khususnya di pedesaan, yang kurang partisipasi dari perempuan. Padahal partisipasi itu merupakan ciri dan prasyarat utama dalam pengelolaan pembangunan bagi kepentingan masyarakat dalam Musrenbang. Belum lagi, tantangan jaman yang menuntut akuntabilitas, transparansi, dan demokratisasi hanya bisa dicapai apabila konsep kesetaraan telah terjadi baik dalam hubungan pemerintahan vertikal maupun pemerintahan horizontal.

Di samping itu, seringkali peserta Musrenbang ini lebih banyak didominasi oleh para pejabat terkait. Bahkan untuk beberapa LSM dan kelompok masyarakat yang ingin ikut dalam forum Musrenbang harus mendaftarkan diri dulu yang belum tentu disetujui. Selain harus lebih proaktif, mereka juga tidak memiliki hak suara penuh. Banyak usulan strategis yang masuk, juga seringkali tidak terakomodasi dan kandas pada tingkatan Musrenbang yang lebih tinggi. Juga, pelaksanaan Musrenbang dari satuan unit paling rendah di tingkat desa/kelurahan juga masih berjalan top-down. Mekanisme perwakilan masyarakat lebih banyak diwakili oleh elit dan tokoh masyarakat.

Karena problema itulah, agar Musrenbang benar-benar menjadi forum/wadah bagi semua golongan masyarakat, terutama kaum perempuan, Pemerintah Kota Banda Aceh melakukan inisiasi membentuk Musyawarah Rencana Aksi Perempuan (MUSRENA). Di samping sebagai sarana dan wadah untuk memperluas partisipasi perempuan dalam proses perencanaan pembangunan, Musrena ini juga sekaligus sebagai suatu mekanisme untuk mempercepat terrealisasinya pengarus-Utamaan Gender (PUG) dalam segala bidang pembangunan nasional, sesuai dengan amanat Instruksi Presiden (Inpres) Nomer 9 Tahun 2003.

Sampai saat ini, Musrena yang diinisiasi dan dikembangkan oleh Pemerintah Kota Banda Aceh ini, merupakan satu-satunya model yang dikembangkan di Indonesia dalam rangka memajukan gender. Oleh karena itu, penelitian secara komprehensif dan mendalam tentang inovasi Musrena di Kota Banda Aceh ini, terutama yang 
Model Musyawarah Rencana Aksi Perempuan (Musrena) Responsif Gender_

berkaitan dengan prinsip-prinsip dasar dan proses pelaksanaan Musrena, serta manfaat Musrena terhadap kebijakan pengarusutamaan gender dan anggaran yang responsif gender, dan kemudian mengembangkan dan menerapkannya di daerah lain dalam rangka mempercepat pelaksanaan kebijakan pengarus-utamaan gender dan anggaran yang responsif gender, adalah sangat penting. Di samping itu, kajian terhadap Musrena ini menjadi penting, karena menurut data yang ada bahwa program pengarus-utamaan gender di Indonesia, berada pada posisi/peringkat 80 diantara 144 negara dunia, dan di posisi 7 diantara 10 negara ASEAN. Dengan demikian diharapkan, pengarus-utamaan Gender (PUG) dan anggaran yang responsif gender dalam segala bidang pembangunan nasional yang diamanatkan oleh konstitusi, dapat segera terwujud.

Penelitian ini memiliki tujuan sebagai berikut:(1) mengelaborasi secara komprehensif dan mendalam tentang inovasi Musrena di Kota Banda Aceh, (2) mengembangkan dan menerapkan model Musrena di daerah lain dalam rangka mempercepat pelaksanaan kebijakan pengarus-utamaan gender dan anggaran yang responsif gender, (3) menyusun rekomendasi kebijakan untuk pemerintah kota/kabupaten agar mengembangkan dan menerapkan model Musrena, sehingga tujuan dari pelaksanaan kebijakan pengarus-utamaan gender dan anggaran yang responsif gender dapat segera terwujud.

\section{B. Pembahasan}

1. Musyawarah Perencanaan Pembangunan (Musrenbang) dan Musyawarah Rencana Aksi Perempuan (Musrena) Sebagai Strategi PUG di Banda Aceh

Musrenbang adalah forum musyawarah tahunan para pemangku kepentingan, baik ditingkat gampong/desa, kecamatan, kabupaten/kota, propinsi dan tingkat nasional mengenai prioritas pembangunan di wilayah tertentu, yang didasarkan pada masukan dari bawah, serta disepakati dalam sebuah dokumen perencanaan 
pembangunan (Randy dan Ryant, 2006 : 51). Konsep Musrenbang juga dimaknai sebagai ruang dan kesempatan berinteraksi antar warga untuk mendiskusikan sesuatu yang berkaitan dengan proses perencanaan pembangunan secara partisipatif (Hanif, 2000 : 67). Proses ini biasanya berakhir dengan pengambilan kesepakatan atau pengambilan keputusan bersama tentang program atau kegiatan prioritas untuk wilayah yang bersangkutan.

Model partisipasi masyarakat ini, secara teoritis dan empiris merupakan cara yang efektif untuk mendorong rasa kepemilikan warga gampong dan memiliki dimensi demokrasi deliberasi (permusyawaratan), dimana masyarakat bermusyawarah dan belajar bersama dalam wilayah lokalnya masing-masing. Berbeda dengan demokrasi perwakilan yang menempatkan prisip voting sebagai pusat dalam pengambilan keputusan publik. Seperti dinyatakan oleh Bessette bahwa legitimasi dalam pembuatan kebijakan hanya berlangsung dari dan melalui musyawarah publik oleh rakyat (Joseph. M, 2011 : 102). Dan inilah yang menjadi inti dari Musrenbang, yaitu partisipasi masyarakat secara penuh dan meluas.

Sedangkan Musrena yang dibentuk berdasarkan Peraturan Walikota Banda Aceh No 25 Tahun 2009, merupakan suatu mekanisme khusus yang diinisiasi oleh Pemerintah Kota Banda Aceh agar partisipasi, konstribusi, serta aspirasi kaum perempuan dapat lebih meningkat dibandingkan dengan apa yang terjadi di dalam Musyawarah Perencanaan Pembangunan (Musrenbang). Lewat Musrena diharapkan perencanaan pembangunan nasional di daerah lebih sesuai dengan kebutuhan dan kepentingan perempuan. Walaupun begitu, Musrena tidak diinisiasi untuk menciptakan proses perencanaan bagi perempuan yang terpisah dari Musrenbang. Perempuan diharapkan juga dapat berpartisipasi dalam proses Musrenbang sebagai mitra yang sejajar dalam masyarakat, sesuai dengan manfaat Musrena yaitu untuk meningkatkan kapasitas perempuan untuk berpartisipasi dalam proses perencanaan pembangunan tahunan. 
Prinsip dasar yang dijadikan pedoman dalam pelaksanaan Musrena di Kota Banda Aceh meliputi prinsip kesetaraan, anggaran yang berkeadilan gender, musyawarah dialogis, anti dominasi, keberpihakan kepada kelompok rentan, anti diskriminasi, dan pembangunan secara holistik.

\section{b. Konsep Pengarus-Utamaan Gender (PUG).}

Secara umum, PUG dapat didefinisikan sebagai suatu strategi untuk mencapai kesetaraan dan keadilan gender melalui kebijakan dan program yang memperhatikan pengalaman, aspirasi, kebutuhan dan permasalahan perempuan dan laki-laki ke dalam perencanaan, pelaksanaan, pemantauan dan evaluasi dari seluruh kebijakan dan program di berbagai bidang kehidupan dan pembangunan. Sementara dalam Inpres No.9/2000 disebutkan PUG adalah (a) sebuah proses yang memasukan analisa gender ke dalam program-program kerja dan seluruh kegiatan instansi pemerintah dan organisasi kemasyarakatan lainnya, mulai dari tahap perencanaan program, pelaksanaan program sampai monitoring dan evaluasi program tersebut, dan (b) merupakan salah satu strategi pembangunan yang dilakukan dengan cara pengintegrasian pengalaman, aspirasi, kebutuhan dan kepentingan perempuan dan laki-laki ke dalam perencanaan, pelaksanaan, pemantauan dan evaluasi dari seluruh kebijakan, program, proyek dan kegiatan di berbagai bidang kehidupan dan pembangunan. Dan tujuan dari PUG itu sendiri adalah untuk memastikan apakah perempuan dan laki-laki memperoleh akses terhadap, berpartisipasi dalam, mempunyai kontrol atas, dan memperoleh manfaat yang sama dari pembangunan.

PUG ini penting untuk diimplementasikan karena beberapa hal (a) untuk mengidentifikasi apakah laki-laki dan perempuan memperoleh akses yang sama terhadap sumberdaya pembangunan, (b) untuk mengidentifikasi apakah laki-laki dan perempuan memiliki peluang berpartisipasi yang sama dalam proses pembangunan, terutama dalam proses pengambilan keputusan, (c) 
untuk mengidentifikasi apakah laki-laki dan perempuan memiliki kontrol yang sama atas sumber daya pembangunan, dan (d) untuk mengidentifikasi apakah laki-laki dan perempuan memperoleh manfaat yang sama dari hasil pembangunan. Oleh karena itu, ada beberapa keuntungan yang dapat diperoleh dari implementasi PUG, yaitu diharapkan dapat teridentifikasi apakah laki-laki dan perempuan (a) memperoleh akses yang sama kepada sumberdaya pembangunan, (b) berpartisipasi yang sama dalam proses pembangunan, termasuk proses pengambilan keputusan, (c) memiliki kontrol yang sama atas usmberdaya pembangunan, dan (d) memperoleh manfaat yang sama dari hasil pembangunan.

\section{c. Konsep Gender Budgeting (Anggaran yang Responsif Gender).}

Perdebatan mengenai gender budget (yang seringkali disebut juga sebagai gender sensitive budget, women's budget) hingga saat ini masih berlangsung di kalangan aktivis perempuan di berbagai negara (Budlender, 2002 : 12). Sebagian aktivis perempuan menganggap gender budget merupakan anggaran khusus untuk program perempuan saja. Sedangkan di sisi lain ada juga yang memiliki pendapat bahwa gender budget merupakan dana tersendiri untuk program yang berkaitan dengan perempuan, tapi program tersebut dampak positifnya tidak hanya dinikmati oleh perempuan saja, tetapi juga bisa dinikmati oleh laki-laki.

Pemisahan anggaran dalam pembangunan untuk perempuan dan laki-laki, sebenarnya tidak diperlukan. Dalam konsep gender sensitive budget, yang lebih diutamakan adalah adanya keadilan dalam alokasi anggaran. Misalnya, dalam bidang pendidikan, banyak anak perempuan dalam sebuah keluarga yang harus "mengalah" tidak memperoleh pendidikan yang lebih tinggi dibandingkan dengan saudara laki-lakinya. Hal itu terjadi karena posisi jender yang tidak setara. Anak laki-laki mendapat kesempatan dalam pendidikan, karena nantinya ia harus menopang kehidupan keluarga dan menjadi kepala keluarga, sehingga ia harus berpendidikan agar 
mendapat pekerjaan yang baik. Sedangkan anak perempuan, tidak menjadi masalah bila tidak menyelesaikan pendidikannya, karena nantinya akan ada suami yang menghidupinya.

Ketidakadilan jender tersebut dapat diatasi melalui gender budget dalam perencanaan pembangunan dan anggarannya. Dengan konsep ini, anak perempuan dan laki-laki harus mendapatkan hak yang sama dalam pendidikan, tidak melihat pada posisi jendernya. Konsep ini memang terkesan seperti memberikan anggaran khusus untuk perempuan dan anak perempuan. Hal itu terjadi karena selama ini yang mengalami ketidakadilan akibat posisi jender yang tidak setara ini adalah perempuan.

Gender budgeting merupakan sebuah instrumen atau alat bagi negara untuk keadilan dan mengusahakan kesejahteraan seluruh rakyat sebagaimana yang menjadi fungsinya. Gender budgeting bukanlah merupakan anggaran yang terpisah bagi laki-laki dan perempuan. Tetapi gender budgeting merupakan anggaran yang responsif terhadap kebutuhan perempuan dan laki-laki, memberikan manfaat kepada perempuan dan laki-laki, berkontribusi terhadap upaya mengatasi kesenjangan relasi sosial antara perempuan dan laki-laki serta bertujuan untuk mewujudkan kesetaraan dan keadilan gender. Dalam menganalisis alokasi gender budgeting, biasanya dapat dilihat dari 3 (tiga) kategori belanja , yaitu (1) Alokasi anggaran gender specific targeted, yaitu belanja yang diperuntukkan bagi perempuan atau laki-laki dalam komunitas untuk memenuhi kebutuhan khususnya; contoh : alokasi anggaran untuk kesehatan reproduksi perempuan, alokasi anggaran untuk penyediaan alat kontrasepsi bagi perempuan dan laki-laki, alokasi anggaran untuk pasmier, alokasi anggaran untuk penderita kanker prostad, alokasi anggaran untuk sunatan massal, (2) alokasi anggaran untuk meningkatkan kesempatan setah ra dalam pekerjaan, yaitu alokasi yang merupakan alternatif action untuk mewujudkan kesempatan yang setara antara laki-laki dan perempuan terutama dalam lingkungan pemerintahan atau dunia kerja lainnya; contoh : alokasi anggaran untuk pelatihan 
teknologi pertanian bagi perempuan, alokasi anggaran untuk fasilitas penitipan anak di tempat kerja, dan (3) alokasi anggaran umum yang mainstreaming, yaitu alokasi anggaran umum yang menjamin agar pelayanan publik dapat diperoleh dan dinikmati oleh semua anggota masyarakat (laki-laki dan perempuan) ; contoh : alokasi anggaran untuk penyediaan fasilitas WC umum yang proporsional terhadap jumlah pengguna (3 perempuan, 2 laki-laki), alokasi anggaran untuk penyediaan gerbong terpisah bagi laki-laki dan perempuan.

\section{d. Musrena, Pengarus-Utamaan dan Anggaran yang Responsif Gender}

Secara umum Musrena di Kota Banda Aceh bertujuan untuk menciptakan Banda Aceh sebagai kota yang ramah gender. Beberapa tujuan khusus yang ingin dicapai oleh Pemerintah Kota Banda Aceh adalah memastikan partisipasi perempuan dan laki-laki secara aktif dalam perencanaan pembangunan daerah mulai dari tingkat paling rendah (gampong). Melalui partisipasi tersebut akan ada masukan kepada pemerintah tentang aspirasi dan kebutuhan perempuan dan laki-laki yang dapat diintegrasikan di dalam program kerja tahunan dan jangka menengah pemerintah sehingga pembangunan yang holistik dapat dicapai. Program kerja yang disusun secara partisipatif akan memastikan adanya intervensi pemerintah melalui kebijakan atau program terhadap kesenjangan gender yang terjadi di tengah masyarakat.

Musrena juga merupakan forum belajar bagi perempuan untuk terlibat dalam memutuskan suatu rencana aksi berjangka waktu 1 (satu) tahun dan juga sebagai wadah komunikasi yang khusus untuk membicarakan, memusyawarahkan dan menampung aspirasi perempuan, sekaligus membuka ruang dialog antara kelompok-kelompok perempuan dengan pihak-pihak pengambil kebijakan (legislatif dan eksekutif). Musrena dapat dinyatakan sebagai tindakan affirmative action (upaya khusus sementara) yang dilakukan pemerintah Kota Banda Aceh untuk memastikan 
partisipasi perempuan dalam perencanaan, pelaksanaan, monitoring dan penikmatan hasil pembangunan. Tujuan akhir Musrena adalah tersedianya anggaran yang responsif gender baik dalam Anggaran Pendapatan dan Belanja Gampong (APBG) serta Anggaran Pendapatan dan Belanja Kota (APBK).

Dengan dilaksanakannya Musrena ini, maka Pemerintah akan mendapatkan informasi yang bermanfaat terkait dengan kebutuhan perempuan di dalam proses perencanaan pembangunan. Bagi kaum perempuan, Musrena dapat dimanfaatkan untuk meningkatkan kapasitas perempuan dan peran/partisipasinya dalam perencanaan pembangunan daerah serta terpenubinya kebutuhan strategis dan kebutuhan praktis bagi perempuan

Artikel ini menggunakan pendekatan kualitatif, dan mengambil lokasi penelitian di Kota Banda Aceh (Provinsi Aceh) sebagai satusatunya model yang dikembangkan di Indonesia. Sedangkan responden dan informan dari penelitian ini meliputi :

1. Penanggungjawab pelaksanaan MUSRENA (Bappeda dan Kepala Kantor Pemberdayaan Perempuan dan Keluarga Berencana).

2. Tokoh Perempuan.

3. Inong Balee.

4. Pendamping Musrena (Women Development Center/WDC) dan Fasilitator Musrena.

5. Anggota DPRD Kota Banda Aceh.

Pengumpulan data yang akan dilakukan dalam penelitian ini adalah gabungan dari berbagai teknik, yaitu :

Focused Group Discussion (FGD) :

FGD ini juga dimaksudkan untuk melakukan cross-check atas berbagai hasil kajian yang telah diperoleh melalui desk-study dan data sekunder. Informan atau narasumber dalam FGD ini ditentukan secara purposive atas dasar teknik snowball, (yaitu mereka yang terlibat dan memahami proses pembentukan dan pengelolaan Musrena). 
Wawancara Mendalam (Indepth-interview).

1. Desk-study (studi dokumen/ dokumentasi).

\section{Formalisme Musrenbang di Banda Aceh .}

Kota Banda Aceh adalah Ibu Kota Nangroe Aceh Darussalam. Dahulu kota ini ernama Kutaraja, kemudian sejak 28 Desember 1962 namanya diganti menjadi Banda Aceh. Berdasarkan naskah tua dan catatan sejarah, Kerajaan Aceh Darussalam dibangun di atas puing-puing kerajaan-kerajaan Hindu dan Budha seperti Kerajaan Indra Purba, Kerajaan Indra Purwa, Kerajaan Indra Patra, dan Kerajaan Indra Pura, dimana Banda Aceh Darussalam sebagai ibukotanya. Hingga tahun 2012, usia Banda Aceh telah menginjak 807 tahun. Tak heran, selain sebagai pusat pemerintahan, kota Islam tertua di Asia tenggara ini sejak lama telah memainkan peran sebagai pusat kegiatan ekonomi, politik, sosial, budaya, dan pengembangan pendidikan khususnya Islam di wilayah barat Indonesia.

Pada tanggal 26 Desember 2004, kota ini dilanda gelombang pasang tsunami yang diakibatkan oleh gempa 7,9 Skala Richter di Samudera Indonesia. Bencana ini menelan ratusan ribu jiwa penduduk, menghancurkan lebih dari $60 \%$ bangunan kota, dan menjadi salah satu bencana terhebat dalam dua abad terakhir. Kini Kota Banda Aceh telah pulih kembali, tak hanya dari efek destruktif tsunami namun juga konflik berkepanjangan antara pemerintah RI dengan GAM melalui perjanjian Helsinki.

Proses rehabilitasi dan rekonstruksi Banda Aceh dilaksanakan oleh pemerintah pusat melalui Badan Pelaksana Rehabilitasi dan Rekontruksi Aceh dan Nias (BRR), pemerintah kota, maupun bantuan dari badan-badan dunia dan berbagai Negara Donor bersama NGO. Kini kota yang dikenal dengan sebutan Serambi Mekkah ini dipimpin oleh Mawardi Nurdin selaku Walikota. Ia terpilih dalam Pilkada pada 11 Desember 2006, yang berpasangan dengan Illiza Saaduddin Djamal [politisi Partai Persatuan Pembangunan (PPP)]. 
Sebelumnya, Mawardi yang merupakan Kepala Dinas Perkotaan dan Permukiman, juga pernah menjabat sebagai Pejabat Sementara (PjS) Walikota Banda Aceh walikota sebelumnya Syarifudin Latief wafat saat peristiwa tsunami.

Pasca diberlakukannya UU Otonomi Khusus daerah istimewa Aceh no. 18 tahun 2001 dan perjanjian damai Helsinki 2005, pemerintahan di Kota Banda Aceh memiliki wewenang dalam pengelolaan keuangan yang berbeda dengan wilayah lain di Indonesia. Perbedaan tersebut terutama menyangkut penerimaan dana alokasi khusus yang diterima oleh Provinsi Banda Aceh melalui dana tambahan bagi hasil minyak dan gas bumi serta dana otonomi khusus. Untuk dana otonomi khusus sebagaimana diatur dalam Qanun No. 2 tahun 2008 tentang tata cara pengalokasian tambahan dana bagi hasil minyak dan gas bumi dan penggunaan dana otonomi khusus, tiap kabupaten dan kota memperoleh bagian $60 \%$ sementara provinsi $40 \%$. Besaran dana otsus mencapai hampir Rp4 trilyun untuk tahun anggaran 2010.

Sebagai ibukota provinsi, Kota Banda Aceh tidak serta merta menerima dana otsus yang lebih besar dibanding kabupaten atau kota di Provinsi NAD. Pembagian dana otsus itu sendiri menurut Qanun No. 2 tahun 2008 tersebut, didasari oleh beberapa indikator. Antara lain: jumlah penduduk, luas wilayah, indeks pembangunan manusia, indeks kemahalan konstruksi, dan indikator lainnya yang relevan. Dengan indikator-indikator tersebut masing-masing daerah bisa menerima dana otsus yang berbeda-beda tiap tahunnya.

Perencanaan pembangunan dan penjaringan aspirasi masyarakat selama ini dilakukan melalui musyawarah perencanaan dan pembangunan (MUSRENBANG) yang dilakukan mulai dari tingkat gampong/kelurahan hingga tingkat kota. Dalam pelaksanaannya, pelibatan langsung dari masyarakat pada forum ini dikritisi oleh berbagai pihak masih sangat minim. Peserta forum lebih didominasi para pejabat terkait. Bahkan untuk beberapa LSM dan kelompok masyarakat yang ingin ikut dalam forum harus 
mendaftarkan diri dulu yang belum tentu disetujui. Selain harus lebih proaktif, mereka juga tidak memiliki hak suara penuh. Banyak usulan strategis yang masuk juga seringkali tidak terakomodasi dan kandas pada tingkatan MUSRENBANG yang lebih tinggi.

Pelaksanaan MUSRENBANG dari satuan unit paling rendah di tingkat kelurahan juga masih berjalan top-down. Mekanisme perwakilan amsyarakat biasanya lebih banyak diwakili oleh ketua atau anggota dewan kelurahan atau biasa disebut tuha peut. Tentang pelaksanaan MUSRENBANG, aktivis LSM di Aceh juga beranggapan masih bersifat simbolis. MUSRENBANG lebih merupakan ajang sosialisasi pada masyarakat sekaligus inkronisasi antara rencana kerja Satuan Kerja Pemerintah Aceh (SKPA) dengan Satuan Kerja Pemerintah Kabupaten/Kota (SKPK).

Di samping itu, dalam hal waktu pelaksanaan, MUSRENBANG sering dikritik terlampau singkat sehingga kemungkinan masyarakat kecil untuk mengkritisi maupun mengklarifikasi usulannya, selain sebagian masyarakat juga seringkali datang dengan tidak mempersiapkan diri sehingga tidak menguasai substansi dari program-program yang diusulkan dinas. Secara teknis, pelaksanaan MUSRENBANG memang dilakukan secara maraton dan paralel. Mulai dari tingkat gampong/kelurahan telah disusun jadwal yang dibuat oleh BAPPEDA Kota. Dalam satu hari dibagi dua jadwal MUSRENBANG kelurahan. Pagi dan siang hari. Masing-masing kelurahan dan gampong mengadakan Musrenbang di meunasah atau kantor kelurahan dalam waktu 3-4 jam.

Mengamati alur perencanaan daerah dimana MUSRENBANG menjadi salah satu kegiatan yang harus dilalui, terlihat jelas bahwa perencanaan lebih bercorak teknokratik-formalistis. MUSRENBANG sebagai mekanisme menjaring aspirasi secara administrative lemah posisinya. Rumusan yang dihasilkan lebih banyak bersifat pembangunan fisik seperti pembangunan pagar kantor kelurahan, perbaikan jalan, dan pembangunan gedung pertemuan. Rumusan usulan telah diformalisasikan dalam bentuk isian form yang sudah 
disebarkan oleh Bappeda.

Pada sisi lain, partisipasi masyarakat belum maksimal dalam Musrenbang. Hal ini disebabkan oleh bentuk undangan kepada peserta musrenbang bermacam-macam. Ada gampong yang menggunakan pengeras suara di meunasah memanggil dan mengundang warganya untuk hadir. Namun ada juga yang terkesan sepi-sepi saja. Sebuah rapat musrenbang di sebuah Kantor Keuchik/ Kelurahan tak jarang hanya dihadiri kurang dari sepuluh orang. Mereka adalah staf kelurahan dan perwakilan dari Bappeda. Beberapa dari mereka beralasan telah ada rapat sebelumnya dengan warga (pra-musrenbang) yang menampung usulan dan masukan untuk kegiatan musrenbang. Maka pada rapat resmi musrenbang sebagaimana diatur dalam jadwal hanyalah menjadi forum dan acara pengesahan dengan staf Bappeda.

Karena MUSRENBANG merupakan forum berjenjang. Dengan demikian, usulan-usulan yang disampaikan di tingkat kelurahan pun akan terus dibawa ke tingkat yang lebih tinggi. Di sinilah persoalan akan muncul. Persoalan dari tingkat bawah belum tentu terakomodir ketika dibawa ke forum yang lebih tinggi. Karenanya, usulan-usulan yang terjadi pada musrenbang tingkat kelurahan kerap merupakan pengulangan usulan tahun sebelumnya.

Persoalan lain yang tidak kalah penting dalam pelaksanaan MUSRENBANG adalah rendahnya keterlibatan/partisipasi perempuan di dalamnya dimana baik berpengaruh secara langsung ataupun tidak, kebijakan-kebijakan dan program yang dicangkan pemerintah kemudian bermasalah terkait sensitivitas gender. Berikut intisarinya:

a. Peserta yang terlibat dalam proses perencanaan, dari MUSRENBANG dari tingkat desa sampai dengan MUSRENBANG di tingkat kota, kebanyakan adalah perangkat pemerintah atau tokoh masyarakat. Kelompok masyarakat awam jarang sekali terlibat, apalagi kelompok perempuan. Kalau pun ada kelompok perempuan yang terlibat, hanya dari kelompok 
PKK atau istri dari aparat pemerintah.

b. Minimnya keterlibatan perempuan mengakibatkan usulan yang dihasilkan kurang berpihak kepada perempuan. Usulan pembangunan fisik dan infrastruktur masih menjadi primadona, tetapi usulan berupa perbaikan gizi, peningkatan kualitas hidup anak melalui pemberian makanan tambahan, posyandu dan usulan serupa lainnya, hampir tidak muncul.

c. Waktu dan tahapan yang harus dilalui oleh masyarakat dalam proses ini sangat panjang dan melelahkan, selain itu tidak ada kepastian bahwa usulan masyarakat akan diakomodir.

d. Minimnya keterwakilan perempuan di DPRD juga sangat menentukan keluaran/hasil dari negosiasi dalam proses perencanaan.

e. Proses perencanaan, seperti halnya proses lain di daur penganggaaran, tidak memperhatikan penerima manfaat dari anggaran yang direncanakan/disusun. Akibatnya beberapa program yang ada menjadi netral gender, bias gender, bahkan buta gender.

\section{MUSRENA sebagai Alternatif MUSRENBANG.}

Berangkat dari persoalan formalisme MUSRENBANG dengan berbagai reniknya di atas, kemudian hadir sebuah ide bertajuk MUSRENA. Forum ini dibentuk atas kerjasama Pemerintah Kota, dengan beberapa lembaga swadaya masyarakat terutama kelompokkelompok perempuan yang difasilitasi bantuan dana dari lembaga nonpemerintah internasional. Tanpa mengecilkan peran yang dimainkan berbagai pihak, tiga inisiator utama yang mengupayakan lahirnya MUSRENA adalah: Wakil Walikota terpilih, Illiza Sa'aduddin Djamal; Kepala Kantor Pemberdayaan Perempuan dan Keluarga Berencana (KPPKB), Badrunnisa; serta Direktur Woman Development Center (WDC), Kusmawati Hatta. Forum yang dimulai sejak tahun 2007 ini dilakukan di tingkat kecamatan dan 
Model Musyawarah Rencana Aksi Perempuan (Musrena) Responsif Gender_

diharapkan dapat menjadi proyek percontohan bagi daerah lain (baik di kota/kabupaten di Provinsi Aceh maupun provinsiprovinsi lain) bagi terbentuknya sebuah forum yang lebih melibatkan partisipasi perempuan secara aktif.

Tujuan Musrena adalah menciptakan Kota Banda Aceh yang Ramah Gender, serta menciptakan Perencanaan Daerah berbasis Gender yang telah mengadaptasi sistem perencanaan bottom up dan top down. Sebagai catatan yang tertuang dalam dokumentasi inisiasi MUSRENA, MUSRENA ini tidak diinisiasi untuk menciptakan proses perencanaan bagi perempuan yang terpisah dari MUSRENBANG. Perempuan diharapkan berpartisipasi di dalam proses MUSRENBANG sebagai mitra yang sejajar di dalam masyarakat. Sesuai dengan MUSRENA, perempuan pun didukung untuk berpartisipasi di dalam MUSRENBANG dan menerapkan keterampilan/keahilan/pengalaman mereka disana. Hal ini mencerminkan manfaat MUSRENA untuk meningkatan kapasitas perempuan untuk berpartisipasi di dalam proses perencanaan pembangunan tahunan. Inisiator utama yang menjalankan program MUSRENA adalah Ibu Wakil Walikota Banda Aceh, Kepala Badan PP dan KB kota Banda Aceh, Direktur Women Development Centre Banda Aceh. Untuk penguatan dibidang pelatihan untuk partisipasi perempuan dalam MUSRENA difasilitasi oleh NGO GTZ- SLGSR. Pendanaan MUSRENA diperoleh dari alokasi anggaran Bappeda Kota BandaAceh, untuk tingkat MUSRENA di kecamatan.

Ada beberapa alasan yang menyebabkan Pemerintah Kota Banda Aceh melaksanakan Musrena sebagai salah satu strategi untuk meningkatkan dan mempercepat partisipasi perempuan dalam pembangunan khususnya dalam perencanaan. Pertama, alasan sosiologis, yaitu masih rendahnya tingkat pertisipasi perempuan dalam proses-proses pengambilan keputusan khususnya dalam perencanaan pembangunan (Musrenbang) mulai dari tingkat gampong sampai ke jenjang yang lebih tinggi. Kedua, alasan politis. Salah satu alasan Pemerintah Kota Banda Aceh melaksanakan 
Musrena adalah karena alasan politis yang ingin menjadikan Kota Banda Aceh sebagai Bandar Wisata Islami yang ramah gender. Untuk mewujudkan janji politik yang telah dituangkan dalam kebijakan tersebut maka penting untuk memastikan adanya perlakuan khusus kepada perempuan dalam menyalurkan aspirasi dan kebutuhanya. Terakomodirnya kebutuhan dan aspirasi perempuan di dalam perencanaan akan berpengaruh terhadap penyusunan APBK yang diharapkan akan memiliki perspektif gender di dalam kebijakan budgeting-nya. Tersedianya anggaran yang responsif gender pada akhirnya diharapkan akan mampu mendorong perwujudan beberapa kebijakan terkait gender diantaranya adalah pencapaian Tujuan Pembangunan Milenium (Millenium Development Goals, MDGs) khususnya yang terkait dengan pemberdayaan perempuan. Secara politik hal ini tentunya dapat mengangkat citra kepala daerah dalam arah pembangunan yang sesuai dengan kebijakan nasional dan internasional. Ketiga, alasan yuridis. Undang Undang Dasar 1945 telah menegaskan hal-hal sebagai berikut : Bahwa setiap orang berhak atas kebebasan berserikat, berkumpul dan mengeluarkan pendapat (Pasal 28E ayat 3), berhak mendapat kemudahan dan perlakuan khusus untuk memperoleh kesempatan dan manfaat yang sama guna mencapai persamaan dan keadilan (Pasal $28 \mathrm{H}$ ayat 2), berhak bebas dari perlakuan yang bersifat diskriminatif atas dasar apapun dan berhak mendapatkan perlindungan terhadap perlakuan yang bersifat diskriminatif (Pasal 28I ayat 2); dan perlindungan, pemajuan, penegakan, dan pemenuhan hak azasi manusia adalah tanggungjawab Negara, terutama pemerintah (Pasal 28I ayat 4).

\section{Problematika dalam Proses dan Tahapan Pelaksanaan Musrena}

Mekanisme Musrena dilakukan di tingkat gampong dan di tingkat kecamatan yang kemudian berlanjut pada Forum Integrasi. Musrena di tingkat gampong bertujuan untuk mencapai kesepakatan usulan kegiatan desa dengan melakukan kajian desa untuk menggali informasi terkait dengan kebutuhan, permasalahan, 
potensi dan sumber daya serta penentuan cita-cita harapan masa depan masyarakat khususnya perempuan, yang akan dibiayai dari APBD dan Alokasi Dana Desa (ADD).

Tokoh perempuan akan mengadakan pertemuan dan memilih 2 (dua) orang perwakilan untuk pelaksanaan Musrena di tingkat kecamatan. Dengan jumlah kecamatan di kota Banda Aceh sebanyak 9 kecamatan, pelaksanaan Musrena di tingkat kecamatan dilakukan sebanyak 3 kali, dimana untuk masing-masing pelaksanaannya menggabungkan 3 kecamatan. Musrena di tingkat kecamatan diikuti oleh dua perwakilan dari masing-masing gampong. Masing-masing pelaksanaan Musrena kecamatan akan dilaksanakan selama 2 (dua) hari. Supaya perempuan dapat mengambil bagian di dalam kedua mekanisme perencanaan, maka Musrena kecamatan dilaksanakan pada waktu yang tidak bersamaan dengan pelaksanaan Musrenbang di kecamatan yang bersangkutan.

Peserta Musrena, terdiri dari: anggota PKK, anggota koperasi wanita terpilih, anggota pengusaha perempuan terpilih, anggota pengajian perempuan terpilih; aparat Kecamatan dan Muspika setempat, serta dihadiri juga oleh perwakilan eksekutif (Bappeda, wakil walikota), WDC, dan Legislatif yang berada di Dapil (daerah pemilihan) masing-masing. Namun demikian, dalam praktiknya terdapat beberapa kendala, misalnya: anggota dewan yang berasal dari Dapil (daerah pemilihan) sebagian besar tidak hadir; serta, peserta yang mewakili tingkat Gampong untuk diutus ke kecamatan bukan peserta yang sudah dilatih oleh WDC melainkan utusan yang ditunjuk personal oleh Geuchik.

Dalam pelaksanaan Musrena pertama, peserta Musrena diberi pengetahuan tentang proses perencanaan pembangunan di daerah, dimana di dalamnya juga dijelaskan tentang Musrena. Setelah terjadi kesamaan pemahaman, barulah dilanjutkan dengan paparan tentang program dan anggaran dari masing-masing SKPD. Maksud dari paparan ini adalah untuk memberikan gambaran kepada peserta Musrena tentang alokasi anggaran yang tersedia. 
Dalam Musrena selanjutnya, paparan tentang proses perencanaan pembangunan tidak lagi diberikan secara khusus dan panjang lebar seperti ketika pelaksanaan Musrena pertama karena peserta Musrena telah memiliki pemahaman tentang hal tersebut. Paparan lebih dititikberatkan pada alokasi anggaran dan program oleh masing-masing SKPD. Dengan demikian, peserta Musrena dapat merumuskan kebutuhan yang akan dituangkan dalam kegiatan dan program lebih efektif. Perbedaan lainnya adalah, dalam Musrena kedua, didahului dengan evaluasi dari realisasi usulan-usulan mereka dalam Musrena pertama (sebelumnya). Walaupun pemberian pengetahuan tentang proses perencanaan pembangunan tidak lagi diberikan secara khusus, tetapi dalam pembukaan Musrena, selalu diberikan pemahaman tentang hal tersebut, dan juga tentang permasalahan terkini yang dihadapi oleh kaum perempuan di Kota Banda Aceh khususnya, dan permasalahan yang dihadapi keluarga secara umum. Dengan demikian, peserta Musrena memperoleh gambaran tentang apa yang akan mereka usulkan dalam Musrena. Dengan kata lain, usulan mereka berangkat dari permasalahan dan kebutuhan riil, bukan berdasarkan keinginan.

Peraturan Walikota No. 52 Tahun 2009 tentang Pedoman Umum Pelaksanaan Musyawarah Rencana Aksi Perempuan (Musrena) memuat Prinsip dasar yang dijadikan pedoman dalam pelaksanaan Musrena di Kota Banda Aceh sebagai berikut:

a. Prinsip kesetaraan. Peserta Musrena mempuyai hak yang sama dan setara untuk menyampaikan pendapat dan dihargai pendapatnya, walaupun berbeda dengan yang lain. Sebaliknya, peserta juga memiliki kewajiban yang setara untuk mendengarkan pandangan orang lain, menghargai perbedaan pendapat dan menjunjung tinggi (menghormati) hasil keputusan forum meskipun tidak sependapat.

b. Prinsip anggaran yang berkeadilan gender. Dalam penetapan prioritas program atau isu, merujuk pada kepentingan serta kebutuhan perempuan dan laki-laki dengan memperhatikan 
anggaran yang tersedia dan memaksimalkan penggunaan yang adil gender.

c. Prinsip musyawarah dialogis. Peserta Musrena memiliki keberagaman tingkat pendidikan, latar belakang, kelompok usia, jenis kelamin, status sosial ekonomi, dan sebagainya. Perbedaan dan berbagai sudut pandang tersebut diharapkan menghasilkan keputusan terbaik bagi kepentingan masyarakat banyak dan gampong di atas kepentingan individu dan golongan.

d. Prinsip anti dominasi. Dalam musyawarah, tidak boleh ada individu/kelompok yang mendominasi sehingga keputusankeputusan yang dibuat tidak lagi melalui proses musyawarah semua komponen masyarakat secara seimbang.

e. Prinsip keberpihakan kepada kelompok rentan. Dalam proses Musrena, diupayakan untuk mendorong individu dan kelompok rentan menyampaikan pendapat dan kebutuhannya dan memastikan kepentingan kelompok rentan diutamakan.

f. Prinsip anti diskriminasi. Peserta Musrena tidak boleh diperlakukan berbeda meskipun memiliki keberagaman dan perbedaan tingkat pendidikan, pandangan politik, kelompok usia, jenis kelamin, status sosial ekonomi, dan sebagainya. Perbedaan tersebut tidak membatasi partisipasi seluruh peserta untuk menyatakan pendapat dan pikirannya.

g. Prinsip pembangunan secara holistik. Musrena dimaksudkan untuk menyusun rencana pembangunan yang dimulai dari level gampong dimana perencanaan pembangunan dilakukan secara holistik bukan rencana kegiatan kelompok atau sektor tertentu saja. Musrena dilakukan sebagai upaya mendorong kemajuan dan meningkatkan kesejahteraan perempuan dan masyarakat seutuhnya sehingga tidak boleh muncul ego-wilayah dalam menentukan prioritas pembangunan.

Musrena tidak diinisiasi untuk menciptakan proses perencanaan bagi perempuan yang terpisah dari Musrenbang. Perempuan sebagai 
mitra yang sejajar dalam masyarakat, sesuai dengan manfaat Musrena yaitu untuk meningkatkan kapasitas perempuan untuk berpartisipasi dalam proses perencanaan pembangunan tahunan.

Sebagaimana diterangkan di muka tentang proses pelaksanaan Musrena, maka seharusnya kegiatan ini diawali dengan rapat persiapan di tingkat gampong sebelum pelaksanaan Musrenbang gampong dengan agenda penjaringan aspirasi perempuan tentang prioritas pembangunan apa yang dibutuhkan oleh perempuan di masing-masing gampong. Namun dalam realitasnya masih terdapat beberapa kelemahan dalam proses pelaksanaannya. Dalam setiap tahun pelaksanaannya sejak tahun 2011 sampai dengan 2013, pertemuan Musrena dilaksanakan pada 3 (tiga) regional kecamatan setiap regional terdiri dari 3 kecamatan. Region 1 yaitu Kecamata Baiturrahman, Banda Raya, dan Kecamatan Lueng Bata. Region 2 yaitu Kecamatan Kuta Alam, Syiah Kuala, dan Ulee Kareng. Region 3 yaitu Kecamatan Kuta Raja, Meuraxa, dan Jaya Baru. Masingmasing kecamatan diikuti oleh dua perwakilan dari masing-masing gampong ditambah dengan perwakilan kecamatan (Istri Camat atau Sekretaris Kecamatan) yang kemudian akan menjadi anggota Tim Monitoring dan Evaluasi serta perwakilan dari Pemerintah Kota Banda Aceh (SKPK).

Pelaksanaan Musrena selama 2 (dua) hari per-regional kecamatan dan mengambil tempat di balee inong (balai/wadah yang disediakan untuk berbagai aktivitas perempuan di gampong atau penggabungan beberapa gampong) dan atau fasilitas lainnya yang ada di kecamatan tersebut. Jika didasarkan pada Peraturan Walikota Banda Aceh No. 52 Tahun 2009 tentang Pedoman Umum Pelaksanaan Musrena, maka seharusnya Musrena dilakukan di masing-masing kecamatan, bukan dengan menggabungkan tiga kecamatan dalam satu pertemuan.

Penggabungan ini didasarkan pada alasan keterbatasan dana yang ada. Konsekuensi dari penggabungan tiga kecamatan dalam satu pertemuan adalah meningkatnya jumlah peserta dalam satu forum 
Model Musyawarah Rencana Aksi Perempuan (Musrena) Responsif Gender_

Musrena Kecamatan (berkisar sampai dengan 40 orang peserta). Jika dibandingkan dengan ketersediaan fasilitas ruangan yang ada di tingkat kecamatan, maka sulit dijumpai fasilitas yang mampu menampung jumlah peserta dalam jumlah besar. Hal ini berpengaruh pada suasana pertemuan yang seringkali tidak kondusif (sesak dan panas) serta terbatasnya kesempatan untuk menyampaikan ide dan pemikirannya.

Sumsidar, (tanggal 24 April 2015) menjelaskan mekanisme pemilihan peserta yang hadir dalam pertemuan Musrena adalah Panitia (Bappeda) mengirimkan surat kepada Camat beserta dengan kriteria peserta yang diharapkan dapat mengikuti kegiatan Musrena yaitu yang mengerti dan tahu kebutuhan gampongnya masingmasing. Camat kemudian menghubungi Keuchik dan Keuchik di tiaptiap gampong yang menentukan dua orang perempuan yang akan mewakili gampong mereka untuk hadir sebagai peserta Musrena Kecamatan

Dalam pelaksanaan yang dilakukan selama ini sebagaimana yang dilaporkan oleh Pelaksana Musrena sebagai hambatan dalam pelaksanaan Musrena pada tahun 2013 adalah kurangnya partisipasi dari para camat untuk memastikan kegiatan Musrena berlangsung dengan baik. Kontribusi yang diberikan oleh pihak kecamatan hanya terlihat dalam aktivitas mendistribusikan undangan yang dikirimkan oleh Bappeda Kota kepada para Keuchik. Kontribusi yang lebih akan terlihat dari kecamatan yang dijadikan lokasi kegiatan Musrena karena pihak kecamatan harus menyediakan fasilitas ruang pertemuan.

Dalam realitasnya tidak setiap gampong mengirimkan dua orang perwakilannya dalam Musrena Kecamatan. Hal ini dapat dibuktikan dengan perhitungan bahwa jika setiap gampong mengirimkan dua orang perempuan sebagai peserta, maka pada Region I untuk Kecamatan Baiturrahman (10 gampong), Bandar Raya (10 gampong) dan Lueng Bata (9 gampong), maka seharusnya terdapat 58 orang peserta perempuan utusan gampong ditambah 
dengan peserta dari kecamatan dan SKPK lainnya. Dengan perhitungan yang sama, untuk Region II akan dihadiri oleh 60 orang peserta dan Region III oleh 62 orang.

Tidak penuhnya keterwakilan peserta dari tiap gampong juga terlihat dari jawaban responden tokoh perempuan (PKK dan organisasi perempuan lainnya di gampong) dimana dari 57 responden terdapat 10,5\% yang tidak mengetahui tentang Musrena dan tidak pernah menghadiri kegiatan dimaksud.

Tahapan persiapan sebagaimana yang diinginkan dalam Pedoman Umum Pelaksanaan Musrena untuk menjaring aspirasi perempuan di tingkat gampong untuk dibawa ke tingkat kecamatan seringkali juga tidak dilakukan. Beberapa responden menyatakan hal tersebut tidak mereka lakukan karena pemberitahuan tentang pelaksanaan Musrena kecamatan diterima dalam tenggang waktu yang sangat dekat (berkisar antara tiga hari sampai dengan satu hari sebelum pelaksanaan kegiatan). Hal ini juga terungkap dalam pernyataan responden yang berasal dari Gampong Deah Raya, Kecamatan Syiah Kuala, yang menyatakan bahwa dirinya memang pernah mengikuti kegiatan Musrena di tingkat kecamatan, tetapi tidak membawa aspirasi perempuan dari gampongnya.

Terkait dengan monitoring dan pelaporan yang merupakan bagian dari proses yang harus dilaksanakan oleh pelaksana Musrena, dalam realitanya masih belum dilaksanakan dengan baik karena pelaporan yang dilakukan masih sangat sederhana dan belum mampu menyampaikan pembelajaran dan rekomendasi dalam setiap pelaksanaan Musrena.

Tingkat pemahaman para pelaksana Musrena tentang kebijakan yang menjadi dasar hukum pelaksanaan Musrena Kota Banda Aceh masih terbatas. Untuk kalangan masyarakat umum, khususnya perempuan yang menjadi peserta Musrena, dasar hukum pelaksanaan Musrena menurut pemahaman mereka adalah kebijakan yang diambil oleh Wakil Walikota (Illiza Saadduddin Djamal) utuk mendorong meningkatnya partisipasi perempuan di 
dalam perencanaan pembangunan. Hal ini tentunya beralasan jika dikaitkan dengan fakta bahwa Musrena sudah dilaksanakan sejak tahun 2007, sementara Peraturan Walikota tentang Pedoman Umum Pelaksanaan Musrena baru dikeluarkan pada tahun 2009. Temuan ini menunjukkan bahwa Pemerintah Kota Banda Aceh masih perlu untuk mensosialisasikan Musrena sebagai sebuah kebijakan resmi Pemerintah Kota Banda Aceh yang berkeinginan untuk mempercepat pengarusutamaan gender di Kota Banda Aceh.

\section{Simpulan}

Upaya peningkatan partisipasi perempuan dan penganggaran resonsif gender melalui Musrena sebagaimana pembahasan di atas menunjukkan adanya sejumlah pekerjaan rumah yang harus diselesaikan. Pertama sosialisasi sebagai sebuah kebijakan resmi Pemerintah Kota Banda Aceh yang berkeinginan untuk mempercepat pengarusutamaan gender di Kota Banda Aceh. Kedua proses pelaksanaan Musrena di Kota Banda Aceh yang dipersyaratkan dilakukan di tingkat Gampong belum dapat terwujud. Sejak tahun 2011 sampai dengan 2014, pelaksanaan Musrena baru dapat dilaksanakan dengan menggabungkan tiga kecamatan di satu titik dan masing-masing Musrena dilaksanakan selama dua hari. Hal ini menyebabkan forum menjadi tidak kondusif karena jumlah peserta yang berlebih dan banyaknya ide serta kondisi yang berbeda di masing-masing kecamatan.

Ada juga masalah kelengkapan sarana dan prasarana yang masih kurang memadai sehingga pelaksanaan Musrena tidak bisa dilaksanakan dengan suasana yang nyaman dan menyenangkan.

Juga partisipasi Camat pada setiap regional dirasakan masih sangat kurang, kontribusi yang diberikan hanya pada pengiriman peserta dari kecamatannya masing-masing. Pemilihan peserta untuk mengikuti Musrena juga tidak dapat dikondisikan dengan maksimal karena walaupun panitia pelaksana (Bappeda Kota Banda 
Aceh) sudah mengirimkan kriteria peserta yang diharapkan, namun kewenangan untuk mengirimkan utusan gampong ada di tangan Keuchik. Peserta yang hadir di Musrena diharapkan membawa usulan prioritas yang sudah didiskusikan bersama dengan seluruh perempuan yang ada di Gampongnya, namun dalam penelitian ini ditemukan bahwa seringkali karena kurang pemberitahuan tentang pelaksanaan Musrena baru didapatkan berkisar antara 3 sampai dengan 1 hari menjelang pelaksanaan Musrena, maka pertemuan para perempuan di tingkat gampong tidak sempat dilaksanakan.

Meski masih ada sejumlah kekurangan dan kendala, semua pihak yang menjadi responden dalam penelitian ini bersepakat bahwa Musrena merupakan forum yang sangat bermanfaat baik untuk meningkatkan kapasitas perempuan, memberikan ruang yang formal bagi perempuan untuk berpartisipasi dalam perencanaan pembanguan, membuka akses informasi dan komunikasi perempuan kepada para pengambil kebijakan, memastikan program-program yang sesuai untuk kebutuhan praktis dan strategis bagi perempuan menjadi prioritas dalam rencana kerja masing-masing SKPK. Berdasarkan berbagai manfaat tersebut, semua pihak berharap pelaksanaan Musrena dimasa yang akan datang dapat terus berlangsung dengan kualitas yang lebih baik.

Sementara itu, pengarusutamaan gender dan anggaran yang responsif gender harus diawali dengan memastikan tersedianya ruang yang baik bagi perempuan untuk ikut berpartisipasi di dalam perencanaan pembangunan. Musrena dilaksanakan dengan kesadaran untuk menyediakan ruang tersebut. Dengan meningkatnya jumlah perempuan yang berpartisipasi dalam perencanaan pembangunan, diharapkan akan muncul usulan-usulan prioritas yang mampu menjawab berbagai kebutuhan praktis dan kebutuhan strategis dengan mempertimbangkan adanya kondisi yang berbeda antara laki-laki, perempuan dan anak serta kelompok-kelompok masyarakat lainnya, khususnya kelompok yang rentan. 


\section{DAFTAR PUSTAKA}

Amin, Nursiti. (2010). Studi Kasus MUSRENA, Banda Aceh: FKKA

BAPPEDA Kota Banda Aceh, (2010). Laporan MUSRENA 2010, Banda Aceh.

Bessette,J.M.(2011).American Government and Politics, deliberation, democracy and citizenship, Boston: Suzanne Jeans.

Debbie Budlender (et.al). (2002). Gender Budgets Make Cents : Understanding Gender Responsive Budgets, Commonwealth Secretariat, London.

Nurcholis, H. (2000). Perencanaan Partisipatif Pemerintah Daerah. Jakarta: P.T.Grasindo.

Peraturan Walikota No. 52 Tahun 2009 Tentang Pedoman Umum Pelaksanaan Musyawarah Rencana Aksi Perempuan (MUSRENA), 6 Oktober 2009.

Siregar, M. Ilhamsyah Siregar, dkk, Studi Anggaran Daerah Berbasis Kebutuhan Kelompok Rentan (Tahun Anggaran 2009 - 2010), Logica II - Gerak, 2010.

Tim Perumus, (2010). Rancangan Qanun Tata Kelola Pemerintahan Berspektif Gender, Logica II

Wrihatnolo, R.R. \& Dwijowijoto. (2006). Managemen Pembangunan Indonesia: Sebuah Pengantar. Jakarta: Elex Media Komputindo.

Wrihatnolo, R., \& Riant Nugroho, R. (2006). Managemen Pembangunan Indonesia; Sebuah Pengantar dan Panduan, Jakarta: PT. Alex Media Kompatindo. 
Halaman ini bukan sengaja untuk dikosongkan 